\title{
EU Cooperation with Third Countries within the New Pact on Migration and Asylum: New Instruments for a 'Change of Paradigm'?
}

\section{Paula García Andrade*}

\section{Introduction}

The New Pact on Migration and Asylum presented by the European Commission on $23^{\text {rd }}$ September 2020 assigns a prominent place to cooperation with third countries of origin and transit of migrations flows, ${ }^{1}$ as previous programmes and plans have, more or less continuously, been doing for more than two decades since the inception of the EU policies on immigration and asylum. As an essential element of any coherent and efficient migration policy, this external dimension receives, in the New Pact, considerable attention, occupying a whole section of the Pact - section 6, devoted to 'working with our international partners' - while numerous references to international cooperation can also be found throughout its other parts.

From the very start of this political orientation document, the Commission recalls how the internal and external dimensions of migration are inextricably linked, ${ }^{2}$ reaffirming the conceptualization of this external dimension as it has traditionally been understood in the EU, as a means to facilitate the achievement of the objectives of the immigration and asylum policies inside the Union. ${ }^{3}$ The priorities that EU partnerships with third countries should pursue range, according to the New Pact, from addressing the root causes of migration and developing legal pathways both for protection and legal migration purposes to fostering readmission and strengthening migration management capacities in third countries. All

Associate Professor of Public International Law and EU Law. Universidad Pontificia Comillas, Madrid.

1 European Commission, 'Communication on a New Pact on Migration and Asylum’ $\operatorname{COM}(2020) 609$ of 23 September 2020.

2 Ibid, 2.

3 See Council, 'A Strategy for the External Dimension of JHA: Global Freedom, Security and Justice', Council doc no 14366/3/05 of 30 November 2005. 
these aims are to be achieved through comprehensive, balanced and mutually beneficial alliances. The Commission is offering what it qualifies as a "fresh start" to assume this endeavour and even a "change of paradigm" in migration cooperation with third countries. ${ }^{4}$

Still those familiar with the international agenda of the EU on migration will have the impression that they have 'heard this song before'. This contribution aims at assessing whether the way in which cooperation with partner countries on migration has been addressed in the New Pact preserves the existing approach or comes with any innovations, especially as far as the tools to be used are concerned. Therefore, the allegedly new Commission's orientations and objectives will firstly be evaluated (2.); secondly, our attention will turn to the instruments foreseen for the design and implementation of the EU international cooperation on migration (3.), by identifying what is new (a), what is missing (b) and what is in excess (c) within the 'toolbox' of this external dimension. As more than one year has elapsed from the presentation of the Pact by the Commission, this analysis will be complemented, when possible, with an assessment of the institutional reactions to the initiatives contained in the New Pact regarding cooperation with third countries, and of the degree of advancement, if any, in their implementation. ${ }^{5}$

\section{A 'Change of Paradigm' in Cooperation with Partner Countries?}

According to the Commission's press release, the Pact presents 'a change of paradigm in cooperation with non-EU countries. ${ }^{6}$ This cooperation will be centred, as stated in the text, on comprehensive, balanced and tailor-

4 European Commission, 'A fresh start on migration: Building confidence and striking a new balance between responsibility and solidarity' (Press Release IP/20/1706, 23 September 2020) <https://ec.europa.eu/commission/presscorner/detail/en/ip_20 1706> accessed 4 November 2021.

5 Although the Commission has taken stock of progress achieved and key developments on the objectives of the Pact in its Report on Migration and Asylum published at the end of September 2021, the degree of implementation of the external dimension is difficult to infer from the unspecific and rather prospective information provided in this report and its annex: see European Commission, Communication 'on the Report on Migration and Asylum', COM(2021) 590 of 29 September 2021, $15 \mathrm{ff}$, and Annex I. The state of play of recent and ongoing engagements of dialogue and cooperation by key partner can be found in Annex II to this report.

6 European Commission, 'A fresh start on migration: Building confidence and striking a new balance between responsibility and solidarity' ( $\mathrm{n} 4)$. 
made migration partnerships, mutually beneficial for the parties involved. ${ }^{7}$ However, the revolutionary character of this approach is extremely doubtful. The approach adopted towards cooperation with third countries on migration has been 'comprehensive', 'global', 'balanced' - and some other synonyms - since the European Council in Tampere in $1999 .{ }^{8}$ The idea was particularly 'officialised' at the Global Approach to Migration (GAM) adopted in $2005,{ }^{9}$ which has been considered, since then, the main political inspiring framework of the external dimension of EU migration policy. According to the GAM, cooperation with partner countries had to combine the diverse dimensions of migration in the search of a balance between fighting against irregular migration, promoting mobility and legal migration, as well as maximising migration - development synergies. Moreover, the idea of "mutually beneficial partnerships", ${ }^{10}$ in which not only EU interests but also those of partner countries are to be taken into account, already appeared at the adoption of the revised Global Approach to Migration and Mobility (GAMM) in 2011,11 which also added the external dimension of asylum. ${ }^{12}$

Thus, we have indeed 'heard this song before'. Neither the goals of mainstreaming migration into the whole external action of the EU and of mobilising different external and internal policies, nor the conditionality between mobility/legal migration opportunities and control-oriented commitments, ${ }^{13}$ are innovative aspects in the EU approach. The same can be said about the political emphasis on cooperation on return, readmission and fighting against migrant smuggling, as these objectives continue to appear as the most relevant pillar of the EU stance on international cooperation on migration. It was the (already) "New Partnership Framework on

$7 \operatorname{COM}(2020) 609$ (n 1), 2.

8 Tampere European Council, Presidency Conclusions, 15-16 October 1999.

9 European Commission, 'Communication on priority actions for responding to the challenges of migration', COM (2005) 621 of 30 November 2005, endorsed by the European Council in its Conclusions of 15-16 December 2005 (annex I), 'Global approach to migration: Priority actions focusing on Africa and the Mediterranean'.

$10 \operatorname{COM}(2020) 609$ (n 1), 17.

11 European Commission, 'Communication on The Global Approach to Migration and Mobility', $\operatorname{COM}(2011) 743$ of 18 November 2011.

12 Ibid 5 and 17-18.

13 See Elspeth Guild's contribution in this book; see also Sergio Carrera and others, 'The European Commission's legislative proposals in the New Pact on Migration and Asylum' (European Parliament Study PE 697.130, 2021, July 2021), 45-46. 
Migration" ${ }^{14}$ adopted in the summer of 2016 under the European Agenda on Migration, ${ }^{15}$ that insisted on these aspects and, particularly, brought back the emphasis on securitisation and conditionality between the mutual engagements of EU and Member States, on the one hand, and third countries, on the other, turning thus the 'global' and 'comprehensive' approach into a formality, which is being now simply consolidated. And it was the 2019 reform of the Visa Code which introduced a concrete mechanism to implement conditionality between a third country's cooperation on readmission and the issuance conditions for Schengen visas to its nationals. ${ }^{16}$ That mechanism is considered unfair to EU partners' citizens and prejudicial to good international relations, ${ }^{17}$ while it could also lead to a violation of the engagements contained in the visa facilitation agreement the EU might have concluded with that country. In this regard, the New Pact and its legislative package attempt to consolidate this controversial conditionality principle by extending it, within the Proposal for an Asylum and Migration Management Regulation, to the identification of "any measure" that could improve the readmission cooperation of that country's authorities. ${ }^{18}$

The New Pact also explicitly insists on the traditional "root causes of migration" approach, by which development cooperation is used to reduce

14 European Commission, 'Communication on establishing a new Partnership Framework with third countries under the European Agenda on Migration', $\operatorname{COM}(2016) 385$ of 7 June 2016.

15 European Commission, 'Communication on A European Agenda on Migration', $\operatorname{COM}(2015) 240$ of 13 May 2015.

16 Art 25a) of Regulation (EU) 2019/1155 of the European Parliament and of the Council of 20 June 2019 amending Regulation (EC) No 810/2009 establishing a Community Code on Visas (Visa Code) (OJ 2019 L 188/25). The first annual assessment of the third countries' level of readmission cooperation, as required by this provision, was completed by the Commission in February 2021: European Commission, 'Enhancing cooperation on return and readmission as part of a fair, effective and comprehensive EU migration policy', $\mathrm{COM(2021)} 56$ of 10 February 2021.

17 Elspeth Guild, 'Amending the Visa Code: Collective Punishment of Visa Nationals?' (EU Immigration and Asylum Law and Policy Blog, 10 May 2019) <https://eu migrationlawblog.eu/amending-the-visa-code-collective-punishment-of-visa-natio nals/> accessed 4 November 2021.

18 Art. 7 of the Proposal for a Regulation of the European Parliament and of the Council on asylum and migration management, COM(2020) 610 of 23 September 2020. In the negotiations of this regulation, there has been a broad support within the Council for the establishment of the leverage mechanism contained in this provision: Pact on Migration and Asylum - Progress Report, Council doc no 9178/21 of 31 May 2021, 7. 
migration from countries of origin. ${ }^{19}$ Unfortunately, controversial statements are once again put on the table, such as affirming that "assistance will be targeted as needed to those countries with a significant migration dimension". ${ }^{20}$ As we have argued elsewhere, prioritising development assistance to countries posing migration challenges means deviating EU development cooperation policy from its primary objective in the Treaties, which is eradication of poverty. ${ }^{21}$ That deviation appears even more problematic in practice given that funds are limited and therefore devoting part of EU development assistance to migration purposes would mean that the needs of developing countries "without a migration dimension" would be overlooked. The Pact is therefore not only preserving the existing approach on migration cooperation with third countries, but it seems to be also incurring in the same flaws. ${ }^{22}$

EU funding will also be essential to achieve the goal of strengthening migration governance and management in partner countries through capacity building actions. ${ }^{23}$ The latter applies, according to the Pact, to the fields of border management, search and rescue capacities, or well-managed asylum and reception systems. For the reasons stated above, the origin of funding is clearly relevant to this effect. EU financial support will come from AFSJ funds - the Asylum, Migration and Integration Fund and the Border Management and Visa Instrument of the Internal Security Fund,$-{ }^{24}$ and is thus unrelated to development cooperation; but it

19 See Vincent Chetail, 'Migration and Development' in Philippe De Bruycker, Marie De Somer and Jean-Louis De Brouwer (eds), From Tampere 20 to Tampere 2.0. Towards a new European consensus on migration (EPC 2019), 39-48.

$20 \operatorname{COM}(2020) 609$ (n 1), 20.

21 Paula García Andrade, 'EU External Competences in the Field of Migration: How to Act Externally when Thinking Internally?' (2018) 55 CML Rev., 178 ff.

22 See European Parliament, Resolution of 25 November 2020 on improving development effectiveness and the efficiency of aid (INI 2019/2184), para 63, stressing how 'making humanitarian aid and emergency aid allocation conditional on cooperation with the EU on migration or security issues is not compatible with agreed development effectiveness principle”. The European Economic and Social Committee also warns about the "temptation to make development aid and cooperation conditional on the development of migration control and/or readmission policies”, EESC Opinion on a New Pact on Migration and Asylum, SOC/649, adopted at plenary on 27 January 2021, 1.8 and 3.27.

$23 \operatorname{COM}(2020) 609$ (n 1), 20-21.

24 Regulation (EU) 2021/1147 of the European Parliament and of the Council of 7 July 2021 establishing the Asylum, Migration and Integration Fund (OJ 2021 L 251/1); Regulation (EU) 2021/1148 of the European Parliament and of the Council of 7 July 2021 establishing, as part of the Integrated Border Management 
may also come from the new Neighbourhood, Development and International Cooperation Instrument (NDICI). ${ }^{25}$ Migration-related actions to be financed under this instrument are oriented towards supporting migration management and governance, as well as the effective implementation of EU agreements and dialogues on migration with third countries, ${ }^{26}$ thus not exclusively following a root causes or development-oriented approach. Although the NDICI Regulation is founded on the legal basis of the development cooperation policy and also on the one on economic, financial and technical cooperation with third countries, ${ }^{27}$ the distribution of funds and their implementation in partner countries should be monitored in order to avoid the deviation of EU development cooperation from its primary objective.

The Pact also puts explicit emphasis on the operational support to the 'new partnerships' by EU home affairs agencies. ${ }^{28}$ The novelty here might lie in the provisions on external action foreseen at the already existing, at the time of the presentation of the Pact, proposal for a Regulation on a European Agency for Asylum, ${ }^{29}$ on whose adoption agreement has recently been reached at the first reading of the ordinary legislative procedure. ${ }^{30}$ In the mandate of the Agency, cooperation with third countries appears to be more structured and strengthened - including actions, under work-

Fund, the Instrument for Financial Support for Border Management and Visa Policy (OJ 2021 L 251/48).

25 Regulation (EU) 2021/947 of the European Parliament and of the Council of 9 June 2021 establishing the Neighbourhood, Development and International Cooperation Instrument - Global Europe, amending and repealing Decision No 466/2014/EU and repealing Regulation (EU) 2017/1601 and Council Regulation (EC, Euratom) No 480/2009 (OJ 2021 L 209/1).

26 See the preamble (paras 50-51), Art 8.10, Annex II.3 and Annex III.4 of Regulation 2021/947. It is indicated that $10 \%$ of the financial envelope for the Instrument should be dedicated particularly to actions supporting management and governance of migration and forced displacement. The European Council has invited the Commission to report by November 2021 on how it intends to make use of that $10 \%$ of the NDICI-Global Challenges: European Council, Conclusions, 21-22 October 2021, para 16.

27 Articles 209 and 212 TFEU.

28 See Evangelia (Lilian) Tsourdi's contribution in this book.

29 Proposal for a Regulation of the European Parliament and of the Council on the European Union Agency for Asylum and repealing Regulation (EU) 439/2010, $\operatorname{COM}(2016) 271$ of 4 May 2016.

30 Agreement was reached at the end of June 2021 on the Regulation creating an EU Asylum Agency - see Letter to the Chair of the European Parliament Committee on Civil Liberties, Justice and Home Affairs (LIBE), Council doc no 10352/21 of 30 June 2021. 
ing arrangements with third countries' authorities, aimed at promoting Union standards on asylum, assisting their authorities on expertise and capacity-building for their own asylum and reception systems, as well as implementing regional development and protection programmes; support to Member States in the implementation of resettlement schemes; the Agency's participation in the implementation of international agreements concluded by the Union on asylum; as well as the deployment in third countries of liaison officers from the Agency's staff,$-{ }^{31}$ mirroring thus the much more developed external action of the European Border and Coast Guard Agency.

Regarding other objectives of EU cooperation with third countries, the New Pact highlights how "engagement with partner countries will be stepped up across all areas of cooperation". To that effect and although it surprisingly acknowledges that, for asylum, 'possibilities today to work with third countries are limited', ${ }^{32}$ the Commission puts the accent on improving refugee protection worldwide, supporting refugees and their hosting countries, and on developing legal pathways to Europe, both for protection and legal migration purposes. ${ }^{33}$ The Pact is not however very specific on the actions through which the Union will accomplish these objectives, apart from providing funding as well as reinforcing support and mobilising national efforts both on resettlement and legal migration schemes. ${ }^{34}$ Consequently, the main focus of the Pact indeed remains on "containment and deterrence of irregular movements" through cooperation on readmission and fight against migrant smuggling ${ }^{35}$, widely addressed in these new political orientations. ${ }^{36}$

31 See article 35 of the final compromised text annexed ibid.

$32 \operatorname{COM}(2020) 609$ (n 1), 21.

33 Ibid, sections 6.2 and 6.6.

34 Ibid, section 6.6.

35 Violeta Moreno Lax and others, 'The EU Approach on Migration in the Mediterranean' (Report, LIBE Committee, European Parliament PE 694.413, June 2021), 121. See also Erich Pichon, 'The external dimension of the new pact on migration and asylum. A focus on prevention and readmission' (Briefing, European Parliamentary Research Service PE 690.535, April 2021).

36 See sections 2.5, 5 and 6.5 of the Pact. See Madalina Moraru's contribution in this collection. 
3. Assessing the Instruments in the 'Toolbox': What's New, What's Missing, What's in Excess?

Whilst EU cooperation with partner countries occupies a prominent place in the New Pact, detailed attention has not however been paid to clarify the set of instruments the EU and its Member States have at their disposal to implement this external dimension. In the following lines, an assessment will be made on the (limited) innovations as well as the omissions in the New Pact as regards the toolbox for cooperation with third countries, including also what, in my view, should have been left outside the Pact.

\section{a) What is New?}

In addition to refer to already existing instruments such as readmission agreements, status agreements, or visa facilitation commitments, the Pact introduces the idea of launching Talent Partnerships under the objective of developing legal pathways to Europe and, more particularly, advancing cooperation with partner countries on mobility and legal migration. ${ }^{37}$ The proposed new instrument appears as an EU policy framework to cooperate with third countries through Union's coordination and funding directed at better matching labour and skills needs in EU Member States, as well as supporting mobility schemes for work or training and capacity building in labour market, skills intelligence, vocational education, integration of returning migrants and diaspora mobilisation. The Commission's proposal seems inspired from the so-called Global Skills Partnerships, ${ }^{38}$ which are foreseen in the UN Global Compact for Safe, Orderly and Regular Migration $^{39}$ and take the form of bilateral agreements used to foster skills development, by which the country of destination provides capacity building and financing to train potential migrants in countries of origin with the skills needed in the country of destination. As they create skills before migration takes place so that brain drain is avoided and they also include training for non-migrants, they constitute both a migration management and a development tool. Talent partnerships are also presented

$37 \operatorname{COM}(2020) 609$ (n 1), 23.

38 See Centre for Global Development, 'Global Skills Partnership' < https://gsp.cgdev .org/learn-more/> accessed 4 November 2021.

39 Global Compact for Safe, Orderly and Regular Migration, adopted in Marrakech on 10-11 December 2018 and endorsed by the UNGA on 19 December 2018 (A/RES/73/195), para 34.e). 
as 'part of the EU's toolbox for engaging partner countries strategically on migration', ${ }^{40}$ and thus an incentive for control-oriented cooperation. The design and use of these instruments have been discussed in a conference organised by the Commission in June 2021, to which representatives of Member States, the European Parliament as well as social and economic partners attended. Talent Partnerships seem to be open to support the mobility of both students, graduates and skilled workers, providing also opportunities for vocational education, training, integration support for returning migration, diaspora mobilisation, as well as expertise and analysis on employment needs. ${ }^{41}$ The Commission has nonetheless clarified that these instruments rely on the experience of previous pilot projects on legal migration already developed since 2017 under the European Agenda on Migration and focused on African countries. ${ }^{42}$

According to the Pact, a strong engagement of Member States will be needed in the design and implementation of Talent Partnerships, most probably because of the exclusive power they preserve on determining the volumes of admission of migrant workers to the EU under art. 79.5 TFEU, although it is unclear whether these instruments will provide for real schemes for the admission of labour migrants or the real impact that attracting talent to the EU may have on the development of countries of origin. ${ }^{43}$ Unfortunately, only a timid intervention of the Union is offered through this new instrument - mainly in the form of coordination and funding - as in the rest of 'legal pathways', both for legal migration and protection purposes, that the Commission is suggesting. ${ }^{44}$ This evidences,

$40 \operatorname{COM}(2020) 609$ (n 1), 23.

41 European Commission, 'Talent Partnerships: Commission launches new initiative to address EU skills shortages and improve migration cooperation with partner countries', (Press Release IP/21/2921, 11 June 2021) <https://ec.europa.eu/com mission/presscorner/detail/en/IP_21_2921> accessed 4 November 2021. See also the Talent Partnership site within the European Commission website $<$ https://ec.e uropa.eu/home-affairs/policies/migration-and-asylum/legal-migration-and-integrat ion/talent-partnerships_en $>$ accessed 4 November 2021.

42 See European Commission, 'Communication on the Delivery of the European Agenda on Migration', $\operatorname{COM(2017)~} 558$ of 27 September 2017, 19; and $\operatorname{COM}(2021) 590$ (n 5), 21.

43 In this sense, see the EESC Opinion on the New Pact (n 22), 3.32.

44 Such as the Commission Recommendation of 23 September 2020 on legal pathways to protection in the EU: promoting resettlement, humanitarian admission and other complementary pathways, C(2020) 6467. Concerns have been raised on the lack of ambitious proposals in the Pact to provide safe pathways for migrants and asylum seekers: Katharina Eisele and Meenakshi Fernandes, 'The European Commission's New Pact on Migration and Asylum. Horizontal substitute impact 
once again, a certain lack of will on the part of the EU in honouring the Treaty objectives to make the most of its competences to develop 'a common immigration policy' and 'a common European asylum system'.

The New Pact also refers to tailor-made Counter Migrant Smuggling Partnerships with third countries, by which the EU will provide support in capacity building on law enforcement and operational capacities, information exchange and actions on the ground through common operations and joint investigative teams, as well as information campaigns on the risks of irregular migration and on legal alternatives. ${ }^{45}$ As these elements are already being part of the EU external action on migration in the form of common operational partnerships, with the support of EU Agencies also highlighted in the Pact, we may wonder whether we are in front of a formal cooperation instrument of a truly innovative character or just a new label for addressing anti-smuggling cooperation. The renewed EU Action Plan against migrant smuggling for the period 2021-2025, presented by the Commission in September 2021, clarifies to a certain extent this issue, when indicating that one of the main pillars of the Plan consists of the establishment of reinforced cooperation with partner countries and other international organisations through Anti-Smuggling Operational Partnerships, as more structured and coherent frameworks encompassing several components such as assistance in establishing solid legal frameworks against smuggling, building operational capacity of national and local authorities, supporting border management capacities, offering operational support to law enforcement and judicial cooperation, reinforcing cooperation on identity and document fraud or engagement against State-led instrumentalization of migration. ${ }^{46} \mathrm{~A}$ central role in the design and implementation of these partnerships is to be played by Member States authorities and EU agencies, together with the support of CSDP missions on strategic advice and capacity-building activities. ${ }^{47}$

assessment' (Study of European Parliament Research Service PE 694.210, August 2021), 92.

$45 \operatorname{COM}(2020) 609$ (n 1), 16.

46 European Commission, 'Communication on A renewed EU action plan against migrant smuggling (2021-2025)', COM(2021) 591 of 29 September 2021, 12-14.

47 Ibid, 14. 


\section{b) What is Missing?}

Firstly, certainty on the toolbox of the external dimension of EU migration policy is clearly missing in the Pact. More particularly, it remains uncertain whether previous instruments used by the EU to cooperate with third countries on migration would continue to be explored and proposed, such as Mobility Partnerships (MPs) and Common Agendas on Migration and Mobility (CAMMs), the emblematic instruments of the GAMM. Apart from implementing existing ones, ${ }^{48}$ will these general and comprehensive policy frameworks for migration cooperation continue to be offered to new priority countries? Are, for instance, Talent Partnerships conceived as an instrument serving to finally honour the legal migration engagements included in MPs? Will the latter be replaced with new general umbrellalike instruments or will the EU simply address the different dimensions of migration through diverse and specific agreements and arrangements with partner countries? Without having accurate replies to these questions, I would rather bet on the second alternative and thus on the abandonment of MPs and CAMMs as general policy frameworks of cooperation given that the Union has been departing, already in a material sense, from the GAMM in the past years and that the drafting of the Pact and subsequent documentation no longer refer to these instruments. This can be inferred, for instance, from the progress report on the Pact issued by the Council Portuguese Presidency which uses a broader language to refer to new partnerships with third countries in line with the Commission's Pact. ${ }^{49}$

Secondly, a reference to association agreements is also missing in the New Pact as an important tool, in my view, of the EU external action on migration. The potential of this explicit external competence, enshrined in Art. 217 TFEU, to address legal migration issues avoiding the complications inherent to the exercise of Union external competences in this field is

48 MPs have been signed with Moldova, Cape Verde (2008), Georgia (2009), Armenia (2011), Morocco, Azerbaijan, Tunisia (2013) Jordan (2014), and Belarus (2016). CAMMs have been adopted with Nigeria, Ethiopia (2015) and India (2016).

49 The Portuguese Presidency confirms the strong consensus among Member States "for the rapid operationalisation of comprehensive, tailor made and mutually beneficial partnerships with key partner countries" and asks the Commission "to prepare the implementation of a roadmap on mutually beneficial partnerships with third countries of origin and transit”: Council Presidency, Pact on Migration and Asylum - Progress Report, Council doc no 9178/21, 31 May 2021. 
to be highlighted. ${ }^{50}$ In addition to the traditional importance of association agreements for integration purposes by providing, through their migration clauses, a reinforced status of rights for migrants coming from associated countries, ${ }^{51}$ Association Councils have also been used in recent years as tools to formalise migration dialogues with partner countries ${ }^{52}$ or developing cooperation on specific migration-related fields, such as social security coordination. ${ }^{53}$ Considering the relevance that association agreements have for migration purposes and, particularly, in light of the limited attention devoted in the Pact to the strengthening of the legal migration component of EU cooperation with third countries, ${ }^{54}$ it is indeed unfortunate that the Pact does not highlight the impact and added value of these 'global' international agreements.

\section{c) What is in Excess?}

Unfortunately, some other instruments are still there, receiving attention in the Pact as tools of international cooperation on migration. I refer, on the one hand, to military missions and operations launched under the Common Security and Defence Policy (CSDP), which, according to the New Pact, "will continue making important contribution" to the fight against migrant smuggling. ${ }^{55}$ In spite of the advantages for migration cooperation that the mobilisation of all the arsenal of EU external action may

50 García Andrade, 'EU External Competences in the Field of Migration: How to Act Externally when Thinking Internally?' (n 21).

51 See, among others, Steve Peers, 'EC immigration law and EC association agreements: fragmentation or integration?' (2009) 34(4) European Law Review, 628-638. Katharina Eisele, The External Dimension of the EU's Migration Policy. Different Legal Positions of Third-Country Nationals in the EU: A Comparative Perspective (Brill 2014).

52 See Paula García Andrade and Iván Martín, 'EU cooperation with third countries in the field of migration' (Study for the European Parliament PE 536.469, October 2015) <www.europarl.europa.eu/RegData/etudes/STUD/2015/536469/IPOL_S TU\%282015\%29536469_EN.pdf > accessed 4 November 2021, 28-30.

53 See Council decisions establishing the Union's position on social security coordination in the Association Councils of certain North-African and Balkan countries published at OJ $2010 \mathrm{~L} 306$.

54 In this field, the New Pact only refers to the Talent Partnerships addressed in sub-section a) above and to 'additional efforts on visa facilitation', see $\operatorname{COM}(2020)$ 609 (n 1), 23.

$55 \operatorname{COM}(2020) 609$ (n 1), 16. 
have, it is at least debatable, in my view, ${ }^{56}$ whether CSDP instruments may be used for migration purposes in light of the horizontal delimitation of competences. The application of the ECJ doctrine of the adequate legal basis and the mutual non-affectation clause of Art. 40 TEU may rather lead to the need of resorting to a TFEU instrument such as Frontex and its powers to launch joint operations with and in third countries, including capacitybuilding and training activities..$^{57}$

On the other hand, soft law is still present too. Non-legally binding instruments are preserved - implicitly as usual - as a tool for migration management cooperation in the Pact. It is true that the political relevance and added value of soft law instruments of cooperation must be acknowledged, either as a locomotive of subsequent hard law instruments (e.g. MPs) or as a way to achieve - a quite otherwise difficult - consensus at the international level (e.g. UN Global Compacts). It is however worrisome to find an explicit reference to soft law precisely on readmission cooperation. Indeed, the New Pact refers both to "EU agreements and arrangements", 58 the latter exemplified in the Joint Way Forward on migration issues between Afghanistan and the EU, ${ }^{59}$ the EU-Bangladesh Standard Operating Procedures for the Identification and Return of Persons without an Au-

56 We have analysed this issue in García Andrade (n 21), $182 \mathrm{ff}$ and in Paula García Andrade, 'La base jurídica de la celebración de acuerdos internacionales por parte de la UE: entre la PESC y la dimensión exterior del Espacio de Libertad, Seguridad y Justicia. Comentario a la sentencia del Tribunal de Justicia de 14 de junio de 2016, Asunto C-263/14, Parlamento c. Consejo' (2017) 41 Revista General de Derecho Europeo. See Panos Koutrakos, 'The nexus between CFSP/CSDP and the Area of Freedom, Security and Justice' in Steven Blockmans and Panos Koutrakos (eds), Research Handbook in EU Common Foreign and Security Policy, (Edward Elgar Publishing 2018) 296-311.

57 In the draft action plan for Niger, the Commission has announced the negotiation of working arrangements between Frontex and EUCAP Sahel Niger and EUBAM Libya, evidencing the need for, at least, the Agency's involvement in these CSDP missions. Draft Action Plan: Niger, Council doc no 11950/21 of 20 September 2021, 3.

$58 \operatorname{COM}(2020) 609$ (n 1), 21.

59 See Annex to the Commission Decision of 4 October 2016 on the signature on behalf of the European Union of a 'Joint Way Forward on migration issues between Afghanistan and the EU', <https://ec.europa.eu/transparency/documents -register/detail?ref=C(2016)6023\&lang=en $>$ accessed 4 November 2021. 
thorisation to Stay, ${ }^{60}$ the EU-Ethiopia Admission Procedures, ${ }^{61}$ and some other informal EU readmission arrangements, ${ }^{62}$ in which legal safeguards, democratic accountability and monitoring seem all the more necessary. ${ }^{63}$ In addition, the proposed Talent Partnerships are very likely to present the form of non-binding agreements, although we will have to wait for the effective launching of these instruments in practice. To this effect, it should be recalled how the Pact endorses a system "fully grounded on European values and international law", which means that cooperation instruments and their implementation must abide by the safeguards inherent to the rule of law and to other EU structural principles of EU external relations such as institutional balance, democracy and transparency. ${ }^{64}$

60 See Annex to the Commission Decision of 8 September 2017 on the signature of the EU-Bangladesh Standard Operating Procedures for the Identification and Return of Persons without an Authorisation to Stay, $<$ https://ec.europa.eu/tr ansparency/documents-register/detail? ref=C(2017)6137\&lang=en $>$ accessed 4 November 2021.

61 Admission Procedures for the Return of Ethiopians from European Union Member States, <www.statewatch.org/media/documents/news/2018/jan/eu-council-reg ugees-return-ethiopians-15762-17.pdf > accessed 4 November 2021.

$62 \mathrm{Up}$ to now, the EU would have adopted readmission arrangements also with Gambia, Guinea and Ivory Coast: $\operatorname{COM}(2021) 56$ (n 1), 6.

63 See Juan Santos Vara, La dimensión exterior de las políticas de inmigración de la Unión Europea en tiempos de crisis (Tirant lo Blanch 2020), 19-46; Caterina Molinari, 'Parallel Paths that Need to Cross?: EU Readmission Deals and Constitutional Allocation of Powers' (Verfassungsblog, 29 September 2020) $<$ https://verfassungs blog.de/parallel-paths-that-need-to-cross/> accessed 4 November 2021; and Andrea Ott, "The "Contamination" of EU Law by Informalization? International Arrangements in EU Migration Law' (Verfassungsblog, 29 September 2020), <https://ver fassungsblog.de/the-contamination-of-eu-law-by-informalization/> accessed 4 November 2021.

64 See Ramses A. Wessel, 'Normative transformations in EU external relations: the phenomenon of 'soft' international agreements' (2021) 44 (1) West European Politics; and Andrea Ott, 'Informalization of EU Bilateral Instruments: Categorization, Contestation and Challenges', (2020) Yearbook of European Law, 569-601. In particular, we have addressed the specific role to be played by the European Parliament in international soft law instruments in Paula García Andrade, 'The role of the European Parliament in the adoption of non- legally binding agreements with third countries', in Juan Santos Vara and Soledad Sánchez Rodríguez-Tabernero (eds), The Democratisation of EU International Relations through EU Law (Routledge 2018), 115-131. 


\section{Concluding Remarks}

The New Pact on Migration and Asylum presented by the Commission attributes great political importance to its external dimension by qualifying cooperation with partner countries as one of the most salient pillars of the EU migration policy. Even the definition of the EU "comprehensive approach" of the whole policy, inserted in article 3 of the Proposal for an Asylum and Migration Management Regulation, includes cooperation with third countries as its first component. ${ }^{65}$ In addition, the relevance of this external dimension appears uncontroversial and brings together a strong consensus among EU Member States, contrary to the major disagreements that some aspects of the internal dimension of the Pact have stirred up. However, in contrast to the Commission's position, the orientation and objectives the Pact assigns to EU international cooperation on migration do not follow neither a 'change of paradigm' nor a 'fresh start', but 'more of the same', just the existing approach with slight nuances.

The fact that nearly most of the objectives, features and instruments of the cooperation to be established with third countries on migration are not new, probably explains why the emphasis put by the New Pact on effective implementation of the existing rules seems particularly apposite for the external dimension. Indeed, further new instruments for cooperation might not be necessary, the accent is thus to be put in exploiting the toolbox the Union has at its disposal and in honouring the commitments in which it has already engaged.

Precisely, an essential duty to respect when implementing this external dimension and putting into practice the toolbox of cooperation instruments is the need to ensure coordination between the supranational and national levels of action, especially in a field in which the intertwinement of EU and Member States' competences is so evident. ${ }^{66}$ To this effect, the Commission's New Pact highlights that the EU and its Member States

65 Article 3.a) of the Proposal refers to 'mutually-beneficial partnerships and close cooperation with relevant third countries, including on legal pathways for thirdcountry nationals in need of international protection and for those otherwise admitted to reside legally in the Member States addressing the root causes of irregular migration, supporting partners hosting large numbers of migrants and refugees in need of protection and building their capacities in border, asylum and migration management, preventing and combatting irregular migration and migrant smuggling, and enhancing cooperation on readmission'.

66 García Andrade, 'EU External Competences in the Field of Migration: How to Act Externally when Thinking Internally?' (n 21). 
shall act united and calls for an effective and systematic coordination between both levels of action. ${ }^{67}$ The Pact does not specify however - just as the Stockholm Programme ten years ago, which also insisted on this duty of coordination and the need for complementarity between the Union and Member States' action - 68 the ways and means by which this coordination should take place. It appears of little use to reformulate approaches, priorities or instruments if one of the most pressing institutional challenges for the effectiveness of this external dimension is not adequately addressed.

$67 \operatorname{COM}(2020) 609$ (n 1), 18.

68 European Council, 'The Stockholm Programme - An open and secure Europe serving and protecting citizens' (OJ 2010 C 115/1), particularly sections 6 and 7. Regarding the New Pact, the Portuguese Presidency of the Council invited Member States "to share information on the main aspects of their bilateral cooperation in migration and mobility areas, in relation to the issue of strengthening migration partnerships with selected priority countries", which "will serve as an important element for the further implementation of the partnerships": Council doc no $9178 / 21$. 